\title{
Reconstruction of the Process of Legal Education in Shaping the Character of Children in Conflict with Law
}

\author{
Yayang Furi Furnamasari ${ }^{* *}$, Susan Fitriasari ${ }^{2}$ \\ 1,2, Universitas Pendidikan indonesia, Indonesia \\ *Corresponding author.Email: furi2810@upi.edu
}

\begin{abstract}
Juvenile delinquency is one of the complex and comprehensive social problems, which my head of the pace of development because the problem can be detrimental to the safety, peace, and security both spiritual and physical or social life directly or indirectly. Therefore, legal education through both formal and informal coaching to children in trouble with law is expected to change and shape their character for the better, so they continue to grow and develop into shapes that have a hope of the nation's moral character and physically and mentally as well. The implementation of legal education embodied in the personality and skills of coaching talent interests that touch aspects include: 1) The juridical aspect, consists of fostering awareness of law and fostering awareness of state and nation. 2) The moral aspect of religious guidance, sports, and arts. Constraints faced by the education law is psychological child, the child's interest, materials and methods presented are less attractive, facilities and infrastructure, the less effective of the technical implementation, children's low awareness, lack of expertise, and lack of parental support. The impact of implementation of legal education is less optimal knowing that the children can return to do crime again. Therefore, the researcher is expected to the related parties such as parents and relevant agencies in order to assist the coaching process so that the aim of the founding can be realized accordance with the expectations.
\end{abstract}

Keywords : Legal education, Juvenile delinquency, children in conflict with law.

\section{INTRODUCTION}

The State of Indonesia is a state of law, this is stated in Article 1 number 3 of the 1945 Constitution of the Republic of Indonesia (UUD NRI 1945). Therefore, all human behavior, whether carrying out legal actions or not taking legal actions, must comply with applicable regulations [1]. As good citizens, we should also be aware of the applicable laws, because that is our obligation as Indonesian citizens to uphold the law in order to build our beloved Indonesia. The phenomenon of violating the law is not only carried out by adults but also by children when doing acts that are considered to violate the rule of law. Globalization in the fields of communication and information, advances in science and technology, as well as changes in lifestyle, have brought about fundamental social changes that have not more or less affected the psyche of children, causing behavioral deviations or unlawful acts committed by children.

In the explanation of Law No. 3 of 1997 concerning Juvenile Court, it is stated that:
Child delinquency is caused by various factors, including the negative impact of rapid development, the flow of globalization in the field of communication and information, advances in science and technology as well as changes in the lifestyle of some parents, which have brought about social changes in people's lives which greatly affect the values and behavior of children.

The problem of juvenile delinquency is a very complex and comprehensive social problem, meaning that it does not only concern children but also concerns their families and communities, and can even threaten the stability of state security. Thus, the problem of child delinquency is not only an actual problem but also a national problem.

The types of crimes committed by children and adolescents include theft, drugs, murder and rape. Criminal cases committed by children and adolescents are caused by several factors, including the lack of love and care from the family and the lack of guidance from parents. In addition, poverty and social problems are also one of the triggers for the occurrence of child crimes. Delinquency that occurs in children is 
basically influenced by 2 factors consisting of: 1). Intrinsic factors, namely the motivation that arises from within the child himself to pursue positive values 2). Extrinsic factors, namely motivation that arises due to influences from outside the child himself.

Children as the next generation of the nation must get attention and affection from their parents, so that children are protected from actions that violate the law. Children are components in society who are very vulnerable to committing deviant acts, especially if they are in a less supportive environment. We know that criminal acts are not only committed by adults but also children. If the crime is committed by children, then the child is called a criminal child. Other legal regulations that live and apply in the community concerned, there is a deviation from the legal provisions carried out by children, forcing the government to immediately take countermeasures, both preventive (preventive) and in the form of imposing sanctions (repressive).

In legal protection for children who experience behavior problems or naughty children resulting in criminal behavior, students have the right to be examined based on the provisions stipulated in Law no. 3 of 1997 concerning Juvenile Court. Actions that are handed down to naughty children can be returned to their parents, guardians or foster parents, submit to the state for coaching education and job training or submit to departments or correctional organizations engaged in education, coaching, and job training. With regard to the concept of correctional, namely coaching, that children who violate the law need to be fostered through the legal education process. In this case, legal education is a process that is carried out consciously, both formally, informally, and non-formally in fostering, maintaining and improving one's legal quality in a planned and directed manner. Legal education in Indonesia has so far been carried out formally or known as legal education through formal education, especially at the higher education level.

\section{METHOD}

The research method used in this research is a case study, namely a comprehensive description and explanation of various aspects of an individual, a group, an organization (community), a program, or a program or a social situation to one case carried out intensively. A case study is an empirical inquiry that investigates a phenomenon in a real-life context when, the boundaries between phenomenon and context are not clearly evident, and where multiple sources of evidence are utilized.

Case study is a study in which researchers in it carefully investigate a program, event, activity, process, or group of individuals who are limited by the time of the event. This method is carried out intensively, in detail and in depth on a particular group, organization, institution or symptom [2].

The research approach used in this study is a qualitative approach based on 2 reasons. First, the problems examined in research on the legal education process in shaping the character of children who are in trouble with the law require a number of actual and contextual field data. Second, the selection of this approach is based on the relationship of the problem under study with a number of primary data from research subjects that cannot be separated from their natural setting. Therefore, this study uses a qualitative approach.

'Qualitative research is an inquiry process of understanding based on distinct methodological traditions of inquiry that explore a social or human problem. The researcher builds a complex, holistic picture, analysis words, reports detailed views of informants, and conducts the study in a natural setting [3].

The researcher makes a complex picture holistically, analyzes words, reports the views of the informants in detail, and conducts research in natural situations. The main characteristic of concern in qualitative research is concern for "meaning"[4].

\section{RESULTS AND DISCUSSIONS}

\subsection{Implementation of Legal Education in Class II A Men's Prison Tangerang.}

The Purpose of Legal Education in Juridical Aspect: It was stated by prison officials that legal education in the juridical aspect has a number of goals to be achieved, including so that correctional students (andikpas) are expected to be imprisoned in dealing with or in trouble with the law. Furthermore, the head of the prison also said that legal education in the juridical aspect aims to make andikpas return to the right path and be able to socialize with fellow andikpas or prison officers and after andikpas leave or are free they do not violate the law again [5]. Juridical Aspects of Legal Education Materials; According to one of the resource persons, the material provided in legal education on the juridical aspect is material on legal awareness, national insight, love for the land and water and on statutory regulations [6] Juridical Aspects of Legal Education Method; According to prison officials, legal education in the juridical aspect is carried out every two weeks. Usually it is carried out with two activities, namely in the hall and in each block. According to staff prisons and andikpas, for meetings block (block meeting) that in use is in a group (classical treatment), by collecting the entire block on the block each to sit in a circle, then do the delivery masalh and all steam (hidden problems) andikpas [7] Juridical 
Aspect of Legal Education Media; The media used in carrying out juridical aspects of legal education are in the form of guide books that support legal education materials, and the media used in the juridical aspect of legal education are adjusted to the conditions of the facilities and infrastructure in prisons. The Purpose of Moral Aspect Legal Education; The religious activities carried out in prisons aim to make Andikpas closer to God Almighty and realize the mistakes he has made so that Andik has to undergo his rehabilitation period in prison. Meanwhile, sports activities in prisons are illustrated that in general they are carried out well so that they attract andikpas and can eliminate the boredom that andikpas feel during this time, while for art activities, according to andikpas, they are interested because the equipment is quite complete but there is no special trainer in art activities [8]. Moral Aspect Legal Education Materials; The material given in this moral aspect of legal education is about Islam, Christianity, Sports and the Arts. Moral Aspects of Legal Education Methods; In the Men's Prison Class A Tangerang, it is clear that legal education in this moral aspect is something that is strategic and needs special attention and is realized in the fields of religion, sports, and the arts. Moral Aspect Legal Education Media; The media used is in accordance with the existing facilities and infrastructure in prisons. Media in religious activities are in the form of worship equipment, sports equipment and art equipment.

3.2 Obstacles Faced in the Implementation of Legal Education in Class II A Men's Prison Tangerang

Based on the results of the study, according to prison officials, in general, Andikpas' interest in participating in legal education activities in the juridical aspect rose and fell, sometimes they followed it with enthusiasm, but when faced with boredom, Andikpas' interest became erratic. Sometimes feeling excited but sometimes lazy. Based on the research, the legal education process in the juridical aspect of money carried out by the prison does not always run as expected, because there are several obstacles or difficulties encountered. The difficulties faced by adkanpis include: a) Sometimes resource persons rarely come, so legal education is only given to certain andikpas, for example legal education is only given to those with a higher school level, or andikpas who have certain cases. b) The material given to andikpas is not in accordance with the wishes of andikpas. The resource person in delivering the material is less creative. So andikpas feel bored and bored. The resource person conveyed that the material was only theoretical. c) The facilities used are not supported, such as legal education which is carried out in the data room. Where the existing data space is less extensive, while andikpas is quite a lot. In addition, prison officers also experience several difficulties, including: 1) Facilities owned by prisons are not supportive. For example, the condition of a room that is too narrow cannot accommodate andikpas. While the room is a place to carry out legal education. 2) The psychological conditions of andikpas are different because some andikpas are aged 18 years and over. 3) Resource persons sometimes cancel from the schedule that has been set, so the prison must replace his replacement. The informants also found various difficulties in the implementation of legal education in the juridical aspect, namely: (1) the psychological condition of children who went up and down; (2) Andikpas interest tends to rise and fall.

In this moral aspect of education there are no significant difficulties, apart from the ups and downs of andikpas interest. This is because in general the Andikpas have enthusiasm in following legal education in the moral aspect. Andikpas also said that legal education in the moral aspect is often followed, because legal education in the moral aspect is more about practices such as religion, sports and the arts. According to Andikpas, this activity can cure a sense of longing for the family. Moral education in this aspect has a number of expectations and goals that the prison party wants. In religious activities, andikpas are expected to be more pious, want to get closer to God Almighty and live their lives in accordance with religious teachings and rules. Meanwhile, through the fields of sports and the arts, the prison expects andikpas to have physical and spiritual health, to be able to fill their time with more positive things and to develop their skills, interests and talents

\subsection{Results of the Implementation of Legal Education}

Based on the results of the research, it can be seen that there are changes in andikpas after and while undergoing legal education in the juridical aspect, these changes can be seen from the increase in discipline, responsibility and willingness to follow the rules. In addition, it seems that the andikpas are more afraid to violate prison regulations. The desire to socialize well with fellow andikpas, not brutal, not provocative and more self-controlled. However, some of the andikpas who were released, they again violated the law in the community, resulting in them returning to rehabilitation. This is caused by several factors, namely, economic factors, the influence of his friends, the environment and the lack of attention from parents [9]

According to the Head of the Tangerang Men's Prison, after receiving this moral aspect, the andikpas in the prison looked calm, tended to worship diligently, politely, and carried out activities including Tadarusan, praying 5 times a day, Tarawih prayers during the month of Ramadan, breaking the fast together and etc. 
This shows that the level of awareness in the spiritual field increases after they get legal education in the moral aspect. In addition, inner peace which ultimately makes Andikpas become more patient. Do not give up and be more enthusiastic in living life. Because they have a long future. This is a change experienced by Andikpas from the results of education in prison. The impact of legal education on the moral aspect is caused because legal education in the moral aspect is more interested in andikpas, and is practical, so andikpas become more enthusiastic in participating in these activities [10].

\section{ACKNOWLEDGMENTS}

The success of completing the implementation of this research cannot be separated from the support of many parties. Thank you for the research informants who have provided various information regarding the research data.

\section{REFERENCES}

[1] Law No. 3 of 1997 concerning Juvenile Justice of the Republic of Indonesia

[2] Creswell, J. W. 2012. Research design qualitative, quantitative and mixed approach; Sage, California

[3] Creswell, John W, 1998, Qualitative Inquiry and Research Design, Choosing Among Five Traditions, Sage Publication, California

[4] Denzin, Norman K. dan Yvonna S. Lincoln (eds.), 2009, Handbook of Qualitative Research. Terj. Dariyatno dkk, Pustaka Pelajar, Jogjakarta.

[5] Ashby, Nicole, and Neilsen-Hewett, Cathrine, 'Approaches to conflict and conflict resolution in toddler relationships' (2012) 10(2) Journal of Early 145.

[6] Fathurokhman, Ferry, 'The necessity of restorative justice on juvenile delinquency in Indonesia, lessons learned from the Raju and AAL cases' (2013) 17 Procedia Environmental Sciences 967.

[7] Braithwaite, John, 'Traditional Justice'. In Llewellyn, J. J. \& Philpott, D. (eds.), Restorative Justice, Reconciliation and Peacebuilding (New York, United States of America: Oxford University Press, 2014) 214.

[8] Karangan, I., 'Implementation of Law Number 11 of 2012 Concerning Child Related Criminal Justice System Concept Restorative Justice' (2016) 1(1) Pattimura Law Journal 67.

[9] Wangi, Y. T., 'Policy of Development for Juvenile Delinquency in the Perspective of Indonesian
Criminal Justice System Reform (Study on Institute for Special Development Children LPKA Kutoarjo, Central Java, Indonesia)' (2017) 2, JILS 85.

[10] Hardjaloka, Loura, 'Criminal Justice system of Children: an overview Restorative Justice Concept in Indonesia and Other Countries' (2015) 15(1) Jurnal Dinamika Hukum 73. 